\title{
IMPACT OF HANDICRAFT WORKERS IN KERALA
}

\author{
Lakshmi Devaraj, \\ Research Scholar, Department of Commerce and Management, Amritha School of Arts and Science, Amritha Vishwa \\ Vidhyapeetham, Kochi
}

\begin{abstract}
The rich cultural legacy of Kerala is well known for its art and crafts and ecological tourism. Most of the state's crafts are constructed of natural materials and qualified craftsmen play an essential part in their creation. There has been a tradition of creating fine crafts with items such as ivory, bamboo, palm leaves, sea-shells, wooden coconut shells, clay, cloth, metal, stone etc. It has an edge to the state the environmentally friendly craft industry. The present study examines the impact of handicrafts workers in related to their employment, financial aspects, exporting the traditional handicraft products, socio - economic conditions of workers and marketing channels. The study focus to find out the problems of workers and thus helpful to the handicraft development society by providing suitable suggestion
\end{abstract}

\section{HISTORY OF HANDICRAFT WORKERS}

for the development of workers especially in the rural region. The objective of the study is analyse the socio - economic condition of handicraft workers and the problems and issues of workers in handicraft sector in Kerala.

KEY WORDS: Handicraft, workers, socio - economic, coconut shell.

\section{INTRODUCTION}

The handicrafts sector displays the country's cultural diversity, and the products reflect the country's traditions. The sector is extremely important to the country's rural economy. Due to low productivity, low salaries, and drudgery in the workplace, the industry faces numerous issues. The younger generation is uninterested in working in the established industry. number of sectoral development schemes such as cluster approach, advanced tools and handicraft development centers, skill development formation, design and product development schemes and marketing infrastructure creation, handmade tourism initiatives, etc. have been developed to realize the potential of this sector's central government and state government. In Kerala, it is estimated that over 1.7 lakh artisans work in the handicrafts industry. There are 32 different crafts in Kerala which include the carving of ivory, wood and horn, bell metal casting of the hand and coconut shell. Kerala is famous for its precise craftsmanship, which is an integral element of the culture. Kerala handicrafts have a prominent place in the Indian handicrafts map due to their distinct, original creative features and unrivalled sense of colour. Kerala's local arts and crafts industry is so strong that you can find handcrafted items made from a wide range of materials, including wood, bell metal, brass, coconut shell, coconut husk, screw pine, straw, other natural fibers, paper Mache, textiles, Cora grass, cane and bamboo, buffalo horn, and so on. Kerala crafts are mostly associated to our state's customs, festivals, and rituals. The wooden face of a Kathakali dancer is a well-known item that may be found in any wayside store. Although each district in the state has a traditional culture of performing a variety of handicrafts, each district is known for one or two crafts in particular. The straw picture craft is popular in Perinad, which is located in the Kollam area. Bamboo crafts are well-known in Ernakulam and Idukki districts. Bell metal artisans can be found in Alappuzha's Mannar and Chengannur districts, Thrissur's Nadavarambu district, and Kannur's Kunjimangalam district. Wooden elephants are famous in Cherpu, Thrissur. Natural fibre crafts are well-known in the Wayanad and Alappuzha areas.

Handicrafts have a huge potential because they are the key to supporting not only the current standard of millions of artists distributed over the country, but also the growing number of new entrants into the handicrafts industry. Currently, handicrafts do not contribute much to job creation or exporting due to pandemic situation in Kerala and other industry related problems. The handicraft sector, on the other hand, has suffered from its lack of organization, as well as other restraints such as a low level of education, poor wages, low finance, inadequate introduction to new technologies, a lack of market awareness, and a weak policy structure.

Indian handicrafts is the master of creating crafts by hand in India. In ancient Times, humans settled in colonies called tribals and they were used to make utility materials for their basic needs, and that art of making crafts called handicrafts, and the materials called handicrafts goods. Then people began to sell these things on the local markets. It is now time and people in all areas have gotten more evolved and civilized, and craftspeople have begun to trade their products with growing demand and population.

Handicrafts are one of the world's oldest traditions. Among the countless handicrafts found around the world, Indian Handicrafts Items may be traced back to the Indus Valley Civilization, one of the world's earliest civilizations. During the 


\section{International Journal of Engineering Applied Sciences and Technology, 2021 \\ Vol. 6, Issue 4, ISSN No. 2455-2143, Pages 347-353 \\ Published Online August 2021 in IJEAST (http://www.ijeast.com)}

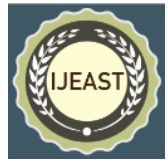

Middle Ages, India's handicrafts sector prospered, and it continued to grow until the arrival of the British in India. The handicrafts sector struggled to keep up with the foreign market after the entry of the British and other colonial forces in India. Because the handicrafts sector relied solely on the abilities of one's hands, completing a masterpiece took time and effort. As a result, the selling price was similarly high. However, because of the machinery generated by the British, goods at a lower cost people began to migrate to the British market. The British take over the handicraft industry because the raw materials needed to produce different goods are from nature and are thus not intended to last longer. As a result, the process of making finished products live longer was time-consuming and expensive. Indian paintings including Thangka Paintings, Miniatures Paintings, Wallis Paintings, Madhubani Paintings, and Tanjore Paintings have become the most enticing temptations for art collectors. Since the Indians exhibited Mughal art styles in the mediaeval period. Stone Work is the second handicraft on our list of Indian handicrafts. People from all around the world have applauded the stonework and sculptures of Indian craftspeople for millennia. This handicraft developed mostly during the mediaeval period, when the Kings of India were particularly interested in the arts. The sculptors were well compensated for their work, and a large portion of the royal treasure was spent building temples and caverns. Wooden Handicrafts come in third on our list of Indian handicrafts. Many people might disagree with our ranking of woodwork as third, but we've been evaluating the relevance of handicrafts from their inception, and it's evident that Stone Works have a stronger case. Having said that, India's Wood Crafts are equally well-known.

\section{OBJECTIVES OF THE STUDY}

1. To analyse the socio - economic condition of handicraft workers.

2. To analyse the impact of handicraft workers in kerala.

3. To study the problems and issues of workers in handicraft sector in Kerala.

\section{RESEARCH METHODOLOGY}

The nature of the analysis was based on descriptive study. The primary data are collected through the structured questionnaire by interview schedule method. Secondary data was collected through books, journals and other Publications. The respondent of the present study are private sector, small \& micro units, medium units and household handicraft workers in Kerala. The Sample size of the study is 268 in accordance with Krejcie Morgan rule and the sample population is covered on 7 districts of Kerala including Alappuzha, Thrissur, Idukki, Wayanad, Kannur, Ernakulam, Kollam .Stratified and simple random sampling is used in the present study. Anova and Correlation are the statistical test used in the study for testing the hypothesis .

\section{Review of Literature}

Syed Khalid Hashmi (2012): The study emphasises the importance as a contributor to the Indian handicrafts industry. Economy by examining the current and potential market and potential risks. Researchers examine the different destinations for the export of Indian Handicrafts. The study examines the product and the market of a developed country in comparative art. In order to evaluate the strengths of Indian Handicraft, the potential threats to Indian Handicraft should be developed. The analysis highlights the role played by the Indian crafts sector. Economy by looking at existing market and prospective dangers and risks. In order to export Indian Handicrafts, scientists analyse several destinations. The research looks at a developed country's goods and market in comparative art. The potential threats to Indian handicraft should be developed to assess the strengths of Indian Handicraft.

Yassir M. Mahgoub (2015) The researcher analyze the impact of handicrafts on the promotion of cultural and economic development for art education students in higher education through handicrafts based on local customs and traditions is investigated. This researcher uses descriptive, analytical, and experimental methodologies. The study's findings are likely to aid planners in the Ministry of Education, who will be able to give handicrafts. An effective technique can have an impact on the teaching and learning of handicrafts, as well as the preservation of their characteristics, as well as their existence and identity.

Magia raptzen (2011) The researchers investigated that students learn the worth of handicrafts in terms of economics and production methods, and that they will utilize the knowledge to boost the income of specific products. The findings show that there is a difference in the quality and worth of handicrafts for students in both the experimental and control groups, indicating that handicrafts promote cultural and economic growth for students in higher education who study art.

Dr. Radhika Kapur (2018) The primary goal of this research paper is to comprehend the relevance of Indian artworks and handicrafts. Arts and the interpretation of India's past, globalisation and the Indian crafts industry, traditions of arts and crafts, types of Indian arts and crafts, characteristics of an artisan and a craft enterprise, problems faced by handicrafts and craftsmen, and schemes for the growth and development of handicrafts are among the areas that have been highlighted

Mohammed Arif, Abhishekh Rai and Babita Balodi ( 2018) The study focuses on skill development among handcraft artists and its impact on job creation, particularly in the state of Jammu and Kashmir. It discusses the impact of government training facilities on artisans, the income of skilled and unskilled artisans, and whether newer generations are interested in the handicraft industry or organizations. The artisans in the sample are from 


\section{International Journal of Engineering Applied Sciences and Technology, 2021 Vol. 6, Issue 4, ISSN No. 2455-2143, Pages 347-353 \\ Published Online August 2021 in IJEAST (http://www.ijeast.com)}

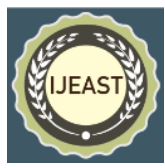

Jammu and Kashmir's Kathua and Anantnag districts, respectively.

Dar and Parrey, (2013), The research was conducted in the state of Jammu \& Kashmir. The handicraft sector provides chances for its craftsmen to improve their standard of living while also assisting them in meeting their social and psychological needs. It adds to State Gross Domestic Product in particular and National Income in general by assisting in the creation of aggregate employment and improving per-capita income. Through foreign exchange, the handicraft sector in Jammu and Kashmir allows the transfer of technical know-how between state qualified workforce and international market players. Indian artisans, who are largely backward, poor, and illiterate, are unable to purchase modern tools and equipment. if they buy the machine they donot have the skill to operate and run the machinery.

Subrahmanian, (2006), According to the researcher, 'artisans' earnings from handcrafted products are appallingly low, and their living conditions are substandard. The study exemplifies the artisan's precarious financial situation. On the social side, the bulk of artisans lack even a basic degree of education, as well as the leadership abilities required to advance in rank. Rural artisans' production skills, particularly indoor artisans', are still conventional and caste-bound, and hence slow to adapt to technological dynamism, resulting in poor output and low earnings.

Santosh kumar (2017)The researcher analyze and focuses on the dynamics of Dhakotha's Soapstone Craft. This report is composed into two sections: a crafts study section and a product design intervention section. Research methodologies, craft introduction, craft location, craft history, available raw materials, craftsmen and current skill sets, tools in use, involved craftsmanship procedures, existing product ranges, and so on are all covered in the crafts study section. This researcher had examined several market specific and end-user focused product design possibilities based on the understandings gained during the crafts study.

Razia Bano (2016) The study aims to examine the handicraft industry's potential in India. The Indian handmade carpet and handicrafts industry is possibly the only sector in rural India that is nearly entirely export oriented, providing direct employment to millions of people and creating chances for unemployed artisans. The carpet and handicraft industry contributes US\$ 847 million in export revenue to the government coffers, in addition to creating jobs for a million weavers and artisans. Handmade carpets from India are known around the world for their exquisite design and bright colour artistry.

Monika dey (2015) The study aims to attempt the potential of India's handmade carpet sector in advancing the country's economic growth and development. The research is based on secondary data gathered from handicraft development institution studies, various organisations, and magazines. The data was analysed using a basic procedure and presented in the form of charts, tables, and diagrams. The study elaborates the suggestion to over come the challenges and impact faced by the handi made carpet sector in all over India especially to the rural region

\section{DATA ANALYSIS AND INTERPRETATION}

\section{AGE OF THE RESPONDENTS} TABLE: 1

\begin{tabular}{|l|l|l|}
\hline RESPONSE & FREQUENCY & PERCENTAGE \\
\hline Below 30 Years & 45 & \multicolumn{2}{|c|}{16.7} \\
30-40 Years & 60 & 22.3 \\
40-60 Years & 155 & 57.8 \\
60 Years Above & 8 & 2.9 \\
Total & $\mathbf{2 6 8}$ & $\mathbf{1 0 0}$ \\
\hline
\end{tabular}

(Source: Primary data)

In the above table describe that $16.7 \%$ of respondents belongs to 30 years, $22.3 \%$ of respondents belongs to 30 to 40 years, $57.3 \%$ of respondents belongs to 40 to 60 years ,2.9\% of respondents belongs to 60 years and above.

\section{GENDER OF THE RESPONDENTS} TABLE: 2

\begin{tabular}{|l|l|c|}
\hline RESPONSE & FREQUENCY & PERCENTAGE \\
\hline Male & 186 & 69.4 \\
Female & 82 & 30.5 \\
Others & 0 & 0 \\
Total & $\mathbf{2 6 8}$ & $\mathbf{1 0 0}$ \\
\hline
\end{tabular}

In the above table it reveals that $69.4 \%$ of respondents are male and $30.5 \%$ of respondents are female.

\section{EDUCATION OF THE RESPONDENTS}

\section{TABLE: 3}

\begin{tabular}{|l|l|c|}
\hline RESPONSE & FREQUENCY & PERCENTAGE \\
\hline $\begin{array}{l}\text { Illiterate } \\
\text { Primary school level }\end{array}$ & 173 & \multicolumn{2}{|c|}{6.3} \\
\hline
\end{tabular}


International Journal of Engineering Applied Sciences and Technology, 2021

Vol. 6, Issue 4, ISSN No. 2455-2143, Pages 347-353

Published Online August 2021 in IJEAST (http://www.ijeast.com)

\begin{tabular}{|l|l|l|} 
Middle school level & 83 & 30.9 \\
High school level & 13 & 4.8 \\
Degree level & 2 & 0.7 \\
Total & $\mathbf{2 6 8}$ & $\mathbf{1 0 0}$ \\
\hline
\end{tabular}

(Source: Primary data)

In the above table explain that $6.3 \%$ of respondents are illiterate, $57.1 \%$ of respondents are primary School educated, $30.9 \%$ of respondents are middle school level educated, $4.8 \%$ of respondents are high school level educated and only $0.7 \%$ of respondents are degree level educated.

\section{EXPERIENCE OF THE RESPONDENTS} TABLE: 4

\begin{tabular}{|l|l|l|}
\hline RESPONSE & FREQUENCY & PERCENTAGE \\
\hline 1 year & 9 & \multicolumn{2}{|c|}{3.3} \\
2-3 years & 12 & 4.47 \\
4-7years & 103 & 38.4 \\
7 years and above & 144 & 53.7 \\
Total & $\mathbf{2 6 8}$ & $\mathbf{1 0 0}$ \\
\hline
\end{tabular}

(Source: Primary data)

In the above table describes that $3.3 \%$ of respondents are less than one year experience, $4.47 \%$ of respondents are $2-3$ years of experience, $38.4 \%$ of respondents are 4 to 7 years experience and $53.7 \%$ of respondents are 7 years and above years experience.

\section{WAGES PER WEEK OF THE RESPONDENTS}

TABLE: 5

\begin{tabular}{|l|l|l|}
\hline RESPONSE & FREEQUENCY & PERCENTAGE \\
\hline Below Rs 1000 & 13 & \multicolumn{2}{|c|}{4.8} \\
1001rs - 2000rs & 185 & 69 \\
2001rs - 3000rs & 50 & 18.6 \\
3001rs -4000rs & 10 & 3.7 \\
Above 4001rs & 10 & 3.7 \\
Total & $\mathbf{2 6 8}$ & $\mathbf{1 0 0}$ \\
\hline
\end{tabular}

In the above table shows that $4.8 \%$ of handicraft workers get wages below rs 1000, $69 \%$ of handicraft workers get wages between rs1001 - 2000, 18.6 percentage of handicraft workers get wages between rs 2001-3000, $3.7 \%$ of handicraft workers get wages between rs 3001-4000, $3.7 \%$ of handicraft workers get wages above rs 4001 in a week.

\section{PROBLEMS FACED BY THE RESPONDENTS TABLE: 6}

\begin{tabular}{|l|l|l|}
\hline RESPONSE & FREQUENCY & PERCENTAGE \\
\hline Very low wages & 68 & \multicolumn{2}{|c|}{25.3} \\
$\begin{array}{l}\text { No government support } \\
\text { Personal financial } \\
\text { problem }\end{array}$ & 43 & 16 \\
$\begin{array}{l}\text { Poor working condition } \\
\text { Lack of adequate raw } \\
\text { materials }\end{array}$ & 7 & 18.6 \\
Living expenses is high & 38 & 1.11 \\
Lack of employment & 60 & 2.6 \\
Other reasons & 2 & 14.1 \\
Total & $\mathbf{2 6 8}$ & 22.1 \\
\hline
\end{tabular}

(Source: Primary data)

In the above table show the problem faced by the handicraft workers that is $25.3 \%$ of workers response with very low wages, $16 \%$ of workers response with lack of Government support, $18.6 \%$ of handicraft workers reacted with personal financial problem, $4.11 \%$ of workers response with poor working condition $2.6 \%$ of workers response with lack of adequate raw material $14.1 \%$ of workers response with living expenses is high, $22.1 \%$ of workers response with lack of employment and $0.72 \%$ of workers response with other reasons which include man made and natural calamities, Shift in demand, emerging of foreign products etc.

\section{SATISFACTION LEVEL OF THE RESPONDENTS IN THE HANDICRAFT SECTOR \\ TABLE: 7}

\begin{tabular}{|c|c|c|}
\hline RESPONSE & FREQUENCY & PERCENTAGE \\
\hline Agree & 49 & 18.2 \\
\hline Disagree & 43 & 16.2 \\
\hline Neutral & 120 & 44.7 \\
\hline Strongly agree & 27 & 8.9 \\
\hline Strongly disagree & 29 & 10.8 \\
\hline Total & 268 & 100 \\
\hline
\end{tabular}

(Source: Primary data)

In the above table describe the satisfaction level of respondents in handicraft sector $18.2 \%$ of respondents agree with the satisfaction level in working handicraft sector, $16.2 \%$ of workers disagree with the satisfaction level in the Handicraft sector, $44.7 \%$ workers neutrally satisfied in working in the 
sector, $8.9 \%$ of workers strongly agree with satisfaction level in working in this sector, $10.8 \%$ of workers disagree with satisfaction level of working in the handicraft industry.

\section{SATISFIED WITH THE WAGE OF THE RESPONDENTS} TABLE: 8

\begin{tabular}{|l|l|l|}
\hline RESPONSE & FREQUENCY & PERCENTAGE \\
\hline Agree & 27 & \multicolumn{2}{|c|}{10.7} \\
Disagree & 74 & 27.6 \\
Neutral & 68 & 25.37 \\
Strongly agree & 58 & 21.6 \\
Strongly disagree & 41 & 15.29 \\
Total & $\mathbf{2 6 8}$ & $\mathbf{1 0 0}$ \\
\hline
\end{tabular}

(Source: Primary data)

In the above table explain the workers satisfaction level in wages, $27.6 \%$ of workers are satisfied with wages, $10.7 \%$ of workers disagree with wages, $25.3 \%$ of workers neutrally satisfied with wages, $21.6 \%$ of workers strongly agree with the wages they earn, 15.2 percentage of worker strongly disagree with wages.

\section{TESTING OF HYPOTHESIS}

H0: There is no significant difference between age and financial impact for handicraft workers.

H1:There is a significant difference between age and financial impact for handicraft workers.

\section{TABLE:9 ANOVA}

\begin{tabular}{|l|l|l|l|l|l|}
\hline $\begin{array}{l}\text { Source of } \\
\text { variance }\end{array}$ & $\begin{array}{l}\text { Sum of } \\
\text { Squares }\end{array}$ & Df & $\begin{array}{l}\text { Mean } \\
\text { Square }\end{array}$ & F & $\begin{array}{l}\text { P- } \\
\text { val } \\
\text { ue }\end{array}$ \\
\hline $\begin{array}{l}\text { Between } \\
\text { Groups }\end{array}$ & 2.465 & 3 & 0.822 & $\begin{array}{l}10 \\
9 .\end{array}$ & $\begin{array}{l}0.0 \\
12\end{array}$ \\
$\begin{array}{l}\text { Within } \\
\text { Groups } \\
\text { Total }\end{array}$ & 83.615 & 264 & 0.427 & 6 & \\
\hline
\end{tabular}

In the above table, it is shown that the results of Anova. it is found that the p-value is 0.012 which is lesser than 0.05 , so the null hypothesis is rejected and the alternative hypothesis is accepted that is "There is a significant difference between age and financial impact for handicraft workers".

\section{TESTING OF HYPOTHESIS}

H0: There is no significant difference between age and employee related impact for handicraft workers.

H1:There is a significant difference between age and employee related impact for handicraft workers.

\section{TABLE:10 Correlations}

\begin{tabular}{|ll|l|l|}
\hline & & AGE & $\begin{array}{l}\text { EMPLOYEE } \\
\text { RELATED } \\
\text { IMPACT }\end{array}$ \\
& $\begin{array}{l}\text { Pearson } \\
\text { Correlation }\end{array}$ & 1 & $.445^{* *}$ \\
& Sig. (2-tailed) & .000 \\
& N & Pearson \\
Correlation & $.445^{* *}$ & 1 \\
$\begin{array}{l}\text { EMPLOYEE } \\
\text { RELATED } \\
\text { IMPACT }\end{array}$ & Sig. (2-tailed) & .000 & 268 \\
& N & 268 & 268 \\
\hline
\end{tabular}

In the above table, it is shown that the results of correlation. it is found that the p-value is .000 which is lesser than 0.05 , so the null hypothesis is rejected and the alternative hypothesis is accepted that is "There is a significant difference between age and employee related impact for handicraft workers".

\section{TESTING OF HYPOTHESIS}

H0: There is no significant difference between age and marketing impact for handicraft workers.

H1: There is a significant difference between age and marketing impact for handicraft workers.

\section{TABLE:11 ANOVA}

\begin{tabular}{|l|l|l|l|l|l|}
\hline $\begin{array}{l}\text { Source of } \\
\text { variance }\end{array}$ & $\begin{array}{l}\text { Sum of } \\
\text { Squares }\end{array}$ & Df & $\begin{array}{l}\text { Mean } \\
\text { Square }\end{array}$ & F & $\begin{array}{l}\text { P- } \\
\text { val } \\
\text { ue }\end{array}$ \\
\hline $\begin{array}{l}\text { Between } \\
\text { Groups }\end{array}$ & 3.026 & 3 & 1.009 & $\begin{array}{l}107 \\
.2\end{array}$ & $\begin{array}{l}0.0 \\
16\end{array}$ \\
\hline
\end{tabular}


International Journal of Engineering Applied Sciences and Technology, 2021

Vol. 6, Issue 4, ISSN No. 2455-2143, Pages 347-353

Published Online August 2021 in IJEAST (http://www.ijeast.com)

\begin{tabular}{|l|l|l|l|l|}
$\begin{array}{l}\text { Within } \\
\text { Groups } \\
\text { Total }\end{array}$ & 114.794 & 264 & 0.586 & \\
\hline
\end{tabular}

In the above table, it is shown that the results of correlation. it is found that the p-value is .0016 which is lesser than 0.05 , so the null hypothesis is rejected and the alternative hypothesis is accepted that is "There is a significant difference between age and marketing impact for handicraft workers".

\section{TESTING OF HYPOTHESIS}

H0: There is no significant difference between gender and export related impact for handicraft workers.

H1: There is a significant difference between gender and export related impact for handicraft workers.

\section{TABLE:12 ANOVA}

\begin{tabular}{|l|l|l|l|l|l|l|}
\hline $\begin{array}{l}\text { Source of } \\
\text { variance } \\
\text { Sum of }\end{array}$ & Mean Square & F & $\begin{array}{l}\text { P- } \\
\text { valu } \\
\text { e }\end{array}$ \\
\hline $\begin{array}{l}\text { Between } \\
\text { Groups }\end{array}$ & .046 & 1 & .046 & .196 & .000 \\
Within Groups & 81.143 & 264 & .233 & & \\
Total & 81.189 & 267 & & & \\
\hline
\end{tabular}

In the above table, it is shown that the results of correlation. it is found that the p-value is .000 which is lesser than 0.05 , so the null hypothesis is rejected and the alternative hypothesis is accepted that is "There is a significant difference between gender and exporting related impact for handicraft workers".

\section{FINDINGS}

1. Majority of the handicraft workers are belongs to the age group of 40 to 60 years (57\%).

2. Majority of the respondents are male handicraft workers (69.4\%) compare to female.

3. Most of the respondents are primary school level educated $(57.1 \%)$ in the handicraft sector. most of them are rural area people the respondents give more importance to the employment rather than education.

4. The workers are well experience in the handicraft sector, majority of the respondents are experienced with 7 years and above.
5. Most of the workers earns rs 1001- rs 2001(69\%), Out of 268 respondents 185 earns wages per week between rs1001 - rs 2001.

6. Majority of the workers response that primary problem faced by the workers is that very low wages $(25.3 \%)$ they received from the private sector industry, small and medium units. Majority of the worker response that secondary problem faced by the household handicraft workers is lack of employment (22.1) and the personal financial problem is also and other factor which include low income, high daily expense, indebtedness, lack of savings and deposits etc.

7. Majority of the workers neutral level of satisfaction in working in the handicraft sector .they are primary educated, no other job skill and age does not permit for another job is the reason for working in the handicraft sector.

8. Majority of the workers are not satisfied with the wages (27.6) they earn from the handicraft work.

9. The employee related impact faced by the handicraft workers is that lack of finance, lack of training and development for rural area handicraft workers inorder to improve the skills, unskilled workers, migration of workers lack of continuous work and availability of adequate raw materials, demand for foreign product instead to traditional and eco- friendly from the customer side preference huge price for raw materials.

10. The market related impact faced by the and craft worker is that low sales promotion, lack of marketing channels, lack of good relationship between customer and handicraft workers, huge competition, lack of market information, availability of modern technologies for marketing products.

11. The financial related impact faced by the workers are lack of savings, low investment, un-education in financial disciplines, reason for indebtedness for workers, improper money management, low income, no other income from other sources, no monetary and monetary benefits from government and units side.

12. The socio - economic impact of handicraft workers are low level of wages, most of the workers are primary school level educated, health impact, economic development impact, most of workers are rural area people are unskilled workers, unawareness about the financial loan for the small medium unit business for handicraft workers, poor living condition, the family member other than the handicraft worker in the family do not have any other job, covid -19 impact affected their living condition and lockdown brought a huge steep down on handicrafts products and workers in different aspects currently, 


\section{International Journal of Engineering Applied Sciences and Technology, 2021 \\ Vol. 6, Issue 4, ISSN No. 2455-2143, Pages 347-353 \\ Published Online August 2021 in IJEAST (http://www.ijeast.com)}

13. The export related impact faced by the workers and handicraft sector include Low financial capability and several international marketing competition, product standardization issues, government restrictions and foreign exchange regulations, exchange rate fluctuation, export incentives decreased, global market recessions due to the impact on covid-19 pandemic situation.

\section{SUGGESTION}

The awareness campaigns will also spark collaborations between craftspeople, urban designers, and rural workers, allowing them to jointly explore prospects. The handicraft development corporation must conduct workshops that improve people's skills and knowledge should be organized at both the rural and urban levels. Conducting of seminars can assist artists in closing the communication gap between the two social representations and fostering a better knowledge of demand and supply. It raises awareness of traditional art. Craftsmen and artisans must comprehend the modern market and its promotional tactics in order to bring art and handicrafts back into the market. The workers must first determine their place in the global market before determining the price of their items. Artists must communicate with customers and teach them about their work and the reason is to motivates clients and creates a bond between the artist and the buyer. Government must take an initiative programs and schemes for the welfare of handicraft workers especially for rural area people, it will help to increase the employment generation in the handicraft sector.

\section{CONCLUSION}

The handicrafts sector contributes significantly to the country's economy. It employs a large number of artisans in rural and semi-urban areas and earns significant foreign exchange for the country. The handicraft sector, on the other hand, has suffered from its lack of organization, as well as other restraints such as a lack of education, low capital, limited exposure to new technologies, a lack of market intelligence, and a weak institutional framework. As a result, it pales in comparison to a well-organized, trained, and systematic sector in a developed country like Germany, U.S,U.K, Canada where it plays a minor role in the total economy.

However, Indian Handicraft still has great potential for growth in the changing situation, with its fundamental strength being that employee strength is abundant and cheap and that being a traditional profession of millions still requires very low investment compared to other countries which exclude China. However, it is under threat from the Chinese economy's expanding clout, as well as greater quality items created in Western countries, as well as their cheap but disciplined labour.

\section{REFERENCE}

1.http://www.indianhandicraftexporter.com/handicraft-stat.ht 2.http://www.indiamart.com/unicraftdelhi/indiamart.com/unicraft.

3.www.texmin.nic.in/.../Outcome Budget $1011 \mathrm{~b}$ and a section 20. $\ 55$.

4.http://www.craftsofindia.com/

5.Manufacture of handicraft in India: A Geographical Encyclopedia of India.

6.Ranjan Aditi - handicraft in india - vol 1

7.openlibrary.org

8.mgutheses.in 